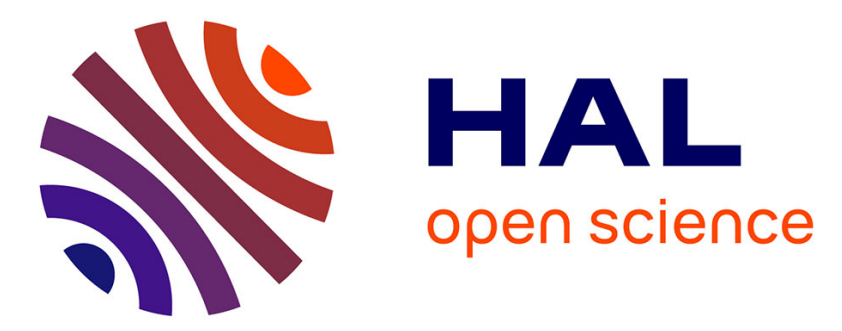

\title{
The oldest 'amphipterygid' damselfly of tropical affinities in the Paleocene of Menat (Zygoptera: Eucaloptera)
}

Romain Garrouste, Sonja Wedmann, Jean-Marc Pouillon, André Nel

\section{- To cite this version:}

Romain Garrouste, Sonja Wedmann, Jean-Marc Pouillon, André Nel. The oldest 'amphipterygid' damselfly of tropical affinities in the Paleocene of Menat (Zygoptera: Eucaloptera). Historical Biology, 2017, 29 (6), pp.818-821. 10.1080/08912963.2016.1247448 . hal-01557349

\section{HAL Id: hal-01557349 \\ https://hal.sorbonne-universite.fr/hal-01557349}

Submitted on 10 Jul 2017

HAL is a multi-disciplinary open access archive for the deposit and dissemination of scientific research documents, whether they are published or not. The documents may come from teaching and research institutions in France or abroad, or from public or private research centers.
L'archive ouverte pluridisciplinaire HAL, est destinée au dépôt et à la diffusion de documents scientifiques de niveau recherche, publiés ou non, émanant des établissements d'enseignement et de recherche français ou étrangers, des laboratoires publics ou privés. 
urn:Isid:zoobank.org:act:3F631097-DE0B-40FA-8227-9C12F55DBAB4

The oldest 'amphipterygid' damselfly of tropical affinities in the Paleocene of Menat (Zygoptera: Eucaloptera)

Romain Garrouste ${ }^{\mathrm{a}}$, Sonja Wedmann ${ }^{\mathrm{b}}$, Jean-Marc Pouillon ${ }^{\mathrm{c}}$ and André $\mathrm{Nel}^{\mathrm{a} *}$

${ }^{a}$ Institut de Systématique, Évolution, Biodiversité, ISYEB - UMR 7205 - CNRS, MNHN, UPMC, EPHE, Muséum national d'Histoire naturelle, Sorbonne Universités, 57 rue Cuvier, CP 50, Entomologie, F-75005, Paris, France; e-mails: garroust@mnhn.fr, anel@mnhn.fr ${ }^{b}$ Senckenberg Forschungsstation Grube Messel, Forschungsinstitut Senckenberg, Markstraße 35, 64409 Messel, Germany; e-mail: Sonja.Wedmann@senckenberg.de c178 rue des Plattieres, F-38300 Nivolas Vermelle, France, e-mail: jmpdb@wanadoo.fr

* Corresponding author

\section{ABSTRACT}

The new damselfly genus and species Valerea multicellulata is described from the Paleocene of Menat (France), a Lagerstatte with many fossil insects, plants and vertebrates with high paleontological value. Aquatic insects are very scarce in this outcrop, this damselfly being the fourth described Odonata. Its closest modern relatives belong to the Amphipterygidae or the Devadattidae, families with very narrow tropical extant distributions. This new fossil allows us to confirm the tropical affinities of the odonatan fauna of the Menat paleolake communities. It also shows that the amphipterygids were clearly more widespread during the 
Paleogene than today, probably in relation to the worldwide warm and equable climate in the Paleocene.

Keywords: Odonata; Zygoptera; Amphipterygoidea; gen. et sp. nov.; Paleocene; palaeoclimate

\section{Introduction}

The Paleocene lacustrine lagerstätte of Menat (Puy-de-Dôme, France) is well known for its very rich and diverse flora (e.g. Laurent, 1912, Piton, 1940) and fauna (vertebrates and insects) (e. g. Piton 1940, Guth 1962; Russel 1967; Matsumoto et al. 2013). Since the first extensive study of the insects of Menat by Piton (1940), several works have been done on the entomofauna, mainly undertaken during the last twenty years by our team (e. g. Nel \& Roy 1996; Nel et al. 1997; Nel \& Auvray 2006; Nel 2007, Nel et al. 2010, Wedmann et al. 2014). The insect fauna is quite diverse, with representatives of nearly all orders, except for the Thysanoptera, Embioptera, Siphonaptera, Zoraptera, and Psocodea. But beetles are the most diverse and abundant group among these insect fossils, followed by Dictyoptera (mainly cockroaches), and Hemiptera (mainly bugs). Despite the fact that Menat is clearly of lacustrine origin, aquatic insects are infrequent. Among them the Odonata are extremely rare, with less than 10 known specimens in a collection of ca. 4000 fossil insects deposited at the MNHN, Paris. Piton (1940) described Lestes zalesskyi and an Aeshna species indet. (incomplete abdomen); both are of very uncertain affinities (Nel \& Paicheler 1994; Nel et al. 1994). Nel et al. (1997) described the third Odonata from Menat, the megapodagrionid Thanetophilosina menatensis. Here we describe a fourth specimen, a partly preserved wing that shows unique characters among the Zygoptera. It is related to the Amphipterygidae or the 
Devadattidae (sensu Dijkstra et al. 2014), two modern monogeneric families living under warm tropical climates.

\section{Material and methods}

Preparation was made using a compressed air needle. The specimen was examined under Nikon SZ10 stereomicroscope and with the Environmental SEM of the MNHN Collection Department, using the mode BSE. Photos were taken with an Olympus E-3 digital camera. Several digital pictures were reconstructed using Helicon Focus and Adobe Photoshop CS2 software. We follow the wing venation nomenclature of Riek \& Kukalová-Peck (1984), emended by Nel et al. (1993) and Bechly (1996). Wing abbreviations are as follows: IR1, IR2, intercalary radial veins; N, nodus; Pt, pterostigma; RA, radius anterior; RP, radius posterior; ScP, subcostal posterior.

\section{Systematic palaeontology}

Class Insecta Linnaeus, 1758

Order Odonata Fabricius, 1793

Suborder Zygoptera Selys, 1854

Families Amphipterygidae Tillyard, 1917 or Devadattidae Dijkstra et al., 2014

Genus Valerea gen. nov.

Type species. Valerea multicellulata sp. nov.

Etymology. Named after Michèle Valère who greatly helped us in organizing the collection of Menat insects.

Diagnosis. Wing characters only. Up to five rows of small cells between C and RA and RA and RP1 distal; pterostigma with basal side long and with short veinlets ending on it; very numerous postnodal crossveins; base of RP2 three cells distal of subnodus. 
Valerea multicellulata sp. nov.

(Figs. 1-2)

Etymology. Named after the great quantity of small cells in apical part of the wing.

Material. Holotype MNHN.F.A57315, stored in the collection of Palaeontology, MNHN, Paris.

Occurrence. Paleocene, spongo-diatomite maar Palaeolake, Menat, Puy-de-Dôme, France.

Diagnosis. That of the genus.

Description. The costo-apical half of a wing, apparently hyaline (pterostigma darker than rest of wing, probable presence of seven transverse darker bands crossing the wing); length of preserved part $25.7 \mathrm{~mm}$; probable length of wing ca. $36.0 \mathrm{~mm}$; distance between nodus and pterostigma $17.8 \mathrm{~mm}$; length of pterostigma $3.3 \mathrm{~mm}$, width $1.2 \mathrm{~mm}$; distance between pterostigma and wing apex $7.6 \mathrm{~mm}$; basal side of pterostigma very long and oblique, with two small crossveins ending on it, distal side of pterostigma distinctly rounded, very long; pterostigma with a crumpled microsculpture; area between costal margin and RA distal of pterostigma very broad with five rows of small irregular cells in-between; no pterostigmal brace but area between RA and RP1 below pterostigma and distal to it very broad and with up to five rows of small cells; ca. 31 postnodal crossveins not aligned with the numerous corresponding postsubnodal crossveins; base of RP2 three cells and $1.8 \mathrm{~mm}$ distal of subnodus; base of IR1 three cells and $2.4 \mathrm{~mm}$ distally; area between IR1 and RP1 with a secondary longitudinal vein and 4-5 rows of cells; area between IR1 and RP2 also widened distally with numerous rows of cells in-between; RA with a pronounced curve near its apex but RP1, IR1 and RP2 only weakly curved; no oblique vein 'O'; IR2 and RP3/4 nearly straight in their distal halves and clearly emerging from RP well basal of nodus, after the great distance between them and the subnodus; MA and MP only fragmentary. 
Discussion. This wing, although fragmentary, is remarkable in the hyper development of the areas between C and RA and RA and RP1 distal of the pterostigma. This situation is quite unique among Odonata, except in some Mesozoic Aeschnidiidae in which the number of rows of cells between RA and RP1 can reach three (Fleck \& Nel 2003). But it never reaches five rows of cells in these areas. This wing is also remarkable in the shape of the pterostigma with its disal side strongly curved and basal side very long and oblique with veinlets ending on it. Similar situations can be observed in some modern Zygoptera, but they are always less pronounced than in this fossil. Among the concerned taxa, Thaumatoneura McLachlan, 1897 (Thaumatoneuridae Tillyard \& Fraser, 1938) or Podopteryx Selys, 1871 (Argiolestidae Fraser, 1957) differ from our fossil in the presence of only 2-3 rows of cells between C and RA, 1-2 rows between RA and RP1, very distal positions of the bases of RP2 and IR1, bases of RP3/4 and IR2 well basal of subnodus, and the longitudinal veins strongly curved near their apices (Münz 1919). Megaloprepus Rambur, 1842 and some other Pseudostigmatidae Kirby, 1890 can have up to 4-5 rows of cells between RA and RP1 and 2-3 rows between C and RA but strongly differs from our fossil in the shape of the pterostigma, distinctly smaller and with basal side not oblique. Their bases of RP2 are also well distal of the subnodus, unlike in our fossil. Some Polythoridae Münz, 1919 have also very oblique basal side of pterostigma but they differ from our fossil in the base of RP2 aligned with subnodus or nearly so, and in a very particular organization of the secondary longitudinal veins between main veins. Diphlebia Selys, 1869 (Philogangidae Kennedy, 1920, Australo-Papua) has also an oblique basal side of pterostigma but no multiple rows of cells at wing apex and a base of RP2 aligned with subnodus too (Münz 1919; Hämäläinen 2008). Devadatta Kirby, 1890 (Devadattidae Dijkstra et al., 2014, Indo-Malaysia) and Amphipteryx Selys, 1853 (Amphipterygidae Tillyard, 1917, sensu Dijkstra et al. 2014, Neotropical) share with our fossil the extremely oblique basal side of pterostigma with several hyperstigmal crossveins ending on it 
(synapomorphy of the Amphipteryginae sensu Bechly 2016), presence of several rows of cells between C and RA distal of pterostigma, bases of RP2 and IR1 3-4 cells distal of subnodus, main veins weakly curved in their distal parts (González-Soriano, 2010; Dow et al., 2015). A further important character is the crumpled microsculpture of the pterostigma, alleged synapomorphy of the 'Amphipterygidae' sensu Bechly (2016) (a group that contains the Amphipterygidae sensu Dijkstra et al. (2014) and the Devadattidae). But none of these have such a multiplication of cells near the apex of the wing as in our fossil. Consequently this fossil corresponds to a new genus and species, probably close to the Devadattidae and the Amphipterygidae but its exact familial affinities remain uncertain.

Remark. The unique other putative fossil amphipterygid is Protamphipteryx basalis Cockerell, 1921, based on a very incomplete costal part of a wing from the Green River Eocene (USA) (Cockerell 1921; Nel \& Paicheler 1992). The attribution of Protamphipteryx to the Amphipterygidae sensu lato is poorly supported and the type specimen should be revised.

\section{Conclusions}

The new fossil genus Valerea could represent the oldest representative for node 34 in Figure 2B in phylogeny proposed by Dijkstra et al. (2014) and thus possibly allows estimation of minimum age for the divergence between them. Valerea could represent a new family but we prefer to avoid erecting one because of the incomplete state of preservation of the material. Further collect will be necessary before doing so. The insect-taphocoenosis of Menat has a very particular pattern with abundance of families with pronounced affinities to a warm climate (speciose and large Buprestidae, very large Cerambycidae, large Fulgoroidea, etc.) (pers. obs.). The extant genus Devadatta is known from the Philippines, Sumatra, Borneo, peninsular Malaysia, Thailand, Vietnam, Laos, and southern China; while Amphipteryx is Mesoamerican. All modern Zygoptera of the amphipterygid or devadattid lineages live in 
intertropical warm and humid environments. Applying the principle of actualism, we conclude that the fossil species described herein had the same climatic requirements as the most closely related extant group. This conclusion corresponds well to the similar paleoclimate that was already proposed for the Paleocene of Menat on the basis of the insects, especially the megapodagrionid Thanetophilosina menatensis, and of the flora (Nel et al. 1997; Wappler et al. 2009).

Although it currently cannot be decided whether the new fossil genus Valerea is more closely related to Devadatta or to Amphipteryx, in either case the fossil indicates a formerly different, probably more encompassing distribution compared with today's distribution of both genera (Fig. 3). This is probably related to the worldwide warm and equable climate in the Paleocene (PETM event).

\section{Acknowledgements}

We thank a lot two anonymous referees for the useful comments on the first version of this paper. We also sincerely thank Mme Leygnac Mathilde, head of the 'EHPAD du Pays de Menat, Les Chaumettes', for her kind help during the collecting of the material. Thanks also to Sylvain Pont (MNHN) for the ESEM and the EDS-SEM analysis.

\section{References}

Bechly, G. 1996. Morphologische Untersuchungen am Flügelgeäder der rezenten Libellen und deren Stammgruppenvertreter (Insecta; Pterygota; Odonata), unter besonderer Berücksichtigung der Phylogenetischen Systematik und des Grundplanes der Odonata. Petalura, Special Volume 2, 1-402.

Bechly, G. 2016. Phylogenetic Systematics of Odonata. Internet site [https://dl.dropboxusercontent.com/u/13756162/Website/odonata/system.htm] 
Cockerell, T.D.A. 1921. Eocene insects from the Rocky Mountains. Proceedings of the United States National Museum, 57, 233-260.

Dijkstra, K.-D.B., Kalkman, V.J., Dow, R.A., Stokvis, F.R. \& Van Tol, J. 2014. Redefining the damselfly families: a comprehensive molecular phylogeny of Zygoptera (Odonata). Systematic Entomology, 39, 68-96.

Dow, R.A., Hämäläinen, M. \& Stokvis, F.R. 2015. Revision of the genus Devadatta Kirby, 1890 in Borneo based on molecular and morphological methods, with descriptions of four new species (Odonata: Zygoptera: Devadattidae). Zootaxa, 4033, 301-349.

Fleck, G. \& Nel, A. 2003. Revision of the Mesozoic family Aeschnidiidae (Odonata: Anisoptera). Zoologica, 153, 1-180.

González-Soriano, E. 2010. A synopsis of the genus Amphipteryx Selys 1853 (Odonata: Amphipterygidae). Zootaxa, 2531, 15-28.

Guth, C. 1962. Un insectivore de Menat. Annales de Paléontologie, 48, 3-10.

Hämäläinen, M. 2008. Philogangidae versus Diphlebiidae: nomenclatoric note on a familygroup name (Zygoptera). Notulae Odonatologicae, 7, 12.

Laurent, L. 1912. Flore fossile des schistes de Menat (Puy-de-Dôme). Annales du Musée d'Histoire Naturelle de Marseille, 14, 1-246.

Matsumoto, R., Buffetaut, E., Escuillié, F., Hervet, S. \& Evans, S.E. 2013. New material of the choristodere Lazarussuchus (Diapsida, Choristodera) from the Paleocene of France. Journal of Vertebrate Paleontology, 33, 319-339.

Münz, P.A. 1919. A venational study of the suborder Zygoptera (Odonata) with keys for the identification of genera. Memoirs of the Entomological Society (of the Academy of Natural Sciences), 3, 1-78.

Nel, A. 2007. Les Bibionidae du Paléocène de Menat (Puy-de-Dôme, France) (Diptera). Bulletin de la Société Entomologique de France, 112, 369-370. 
Nel, A.,\& Auvray, F. 2006. The oldest Vespinae from the Paleocene of Menat (France) (Hymenoptera: Vespidae). Zootaxa, 1344, 59-62.

Nel, A., Martínez-Delclòs, X., Escuillié, F. \& Brisac, P. 1994. Les Aeshnidae fossiles: Etat actuel des connaissances (Odonata, Anisoptera). Neues Jahrbuch für Geologie und Paläontologie, Abhandlungen, 194, 143-186.

Nel, A., Martínez-Delclòs, X., Paicheler, J.-C. \& Henrotay, M. 1993. Les 'Anisozygoptera’ fossiles. Phylogénie et classification (Odonata). Martinia, Numéro Hors Série, 3, 1-311.

Nel, A., Martínez-Delclòs, X., Papier, F. \& Oudard, J. 1997. New Tertiary fossil Odonata from France. (Sieblosiidae, Lestidae, Coenagrioniidae, Megapodagrionidae, Libellulidae). Deutsche Entomologische Zeitschrift, 44, 231-258.

Nel, A. \& Paicheler, J.-C. 1992. Les Odonata fossiles: Etat actuel des connaissances. Huitième partie: Les Calopterygoidea fossiles [Odonata, Zygoptera]. Bulletin de la Société Entomologique de France, 97, 381-396.

Nel, A. \& Paicheler, J.-C. 1994. Les Lestoidea (Odonata, Zygoptera) fossiles: un inventaire critique. Annales de Paléontologie, 80, 1-59.

Nel, A. \& Roy, R. 1996. Revision of the fossil "mantid" and "ephemerid" species described by Piton from the Palaeocene of Menat (France) (Mantodea: Chaeteessidae, Mantidae; Ensifera: Tettigonioidea). European Journal of Entomology, 93, 223-234.

Nel, A., Azar, D. \& Hervet, S. 2010. A new rhopalosomatid wasp in the Paleocene of France (Hymenoptera) Annales de la Société Entomologique de France, (N.S.), 46, 211-215.

Piton, L. 1940. Paléontologie du gisement éocène de Menat (Puy-de-Dôme), flore et faune. Mémoire de la Société d'Histoire Naturelle d'Auvergne, 1, 1-303.

Riek, E.F. \& Kukalová-Peck, J. 1984. A new interpretation of dragonfly wing venation based upon Early Carboniferous fossils from Argentina (Insecta: Odonatoidea) and basic characters states in pterygote wings. Canadian Journal of Zoology, 62, 1150-1166. 
Russell, D.E. 1967. Sur Menatotherium et l'âge paléocène du gisement de Menat (Puy-deDome). In: Problèmes actuels de Paléontologie (Colloques Internationaux du Centre National de la Recherche Scientifique), Paris 164, 483-490.

Wappler, T., Currano, E.D., Wilf, P., Rust, J. \& Labandeira, C.C. 2009. No postCretaceous ecosystem depression in European forests? Rich insect-feeding damage on diverse middle Palaeocene plants, Menat, France. Proceedings of the Royal Society, (B), 276, 42714277.

Wedmann, S., Pouillon J.-M. \& Nel, A. 2014. New Palaeogene horntail wasps (Hymenoptera, Siricidae) and a discussion of their fossil record. Zootaxa, 3869, 33-43.

Figure 1. Valerea multicellulata gen. et sp. nov., holotype MNHN.F.A57315. A, photograph of wing; B, drawing of wing. Scale bars represent $5 \mathrm{~mm}$ (A), $3 \mathrm{~mm}$ (B).

Figure 2. Valerea multicellulata gen. et sp. nov., holotype MNHN.F.A57315. A, Electron scanning photograph of pterostigmal area. B, Electron scanning photograph of pterostigmal area, magnified. Arrows indicate postnodal crossveins ending on basal side of pterostigma. Scale bars represent $1 \mathrm{~mm}$ 


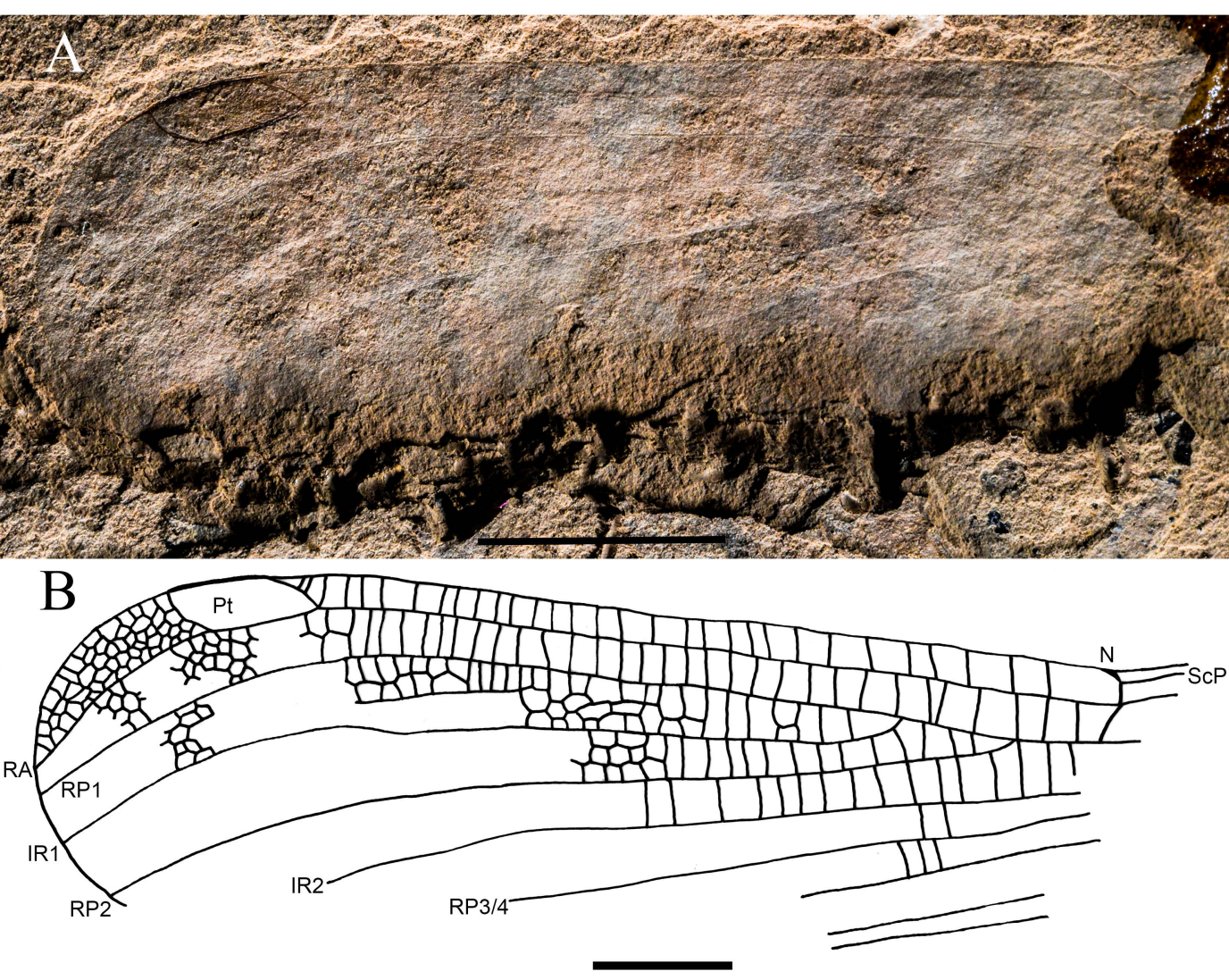




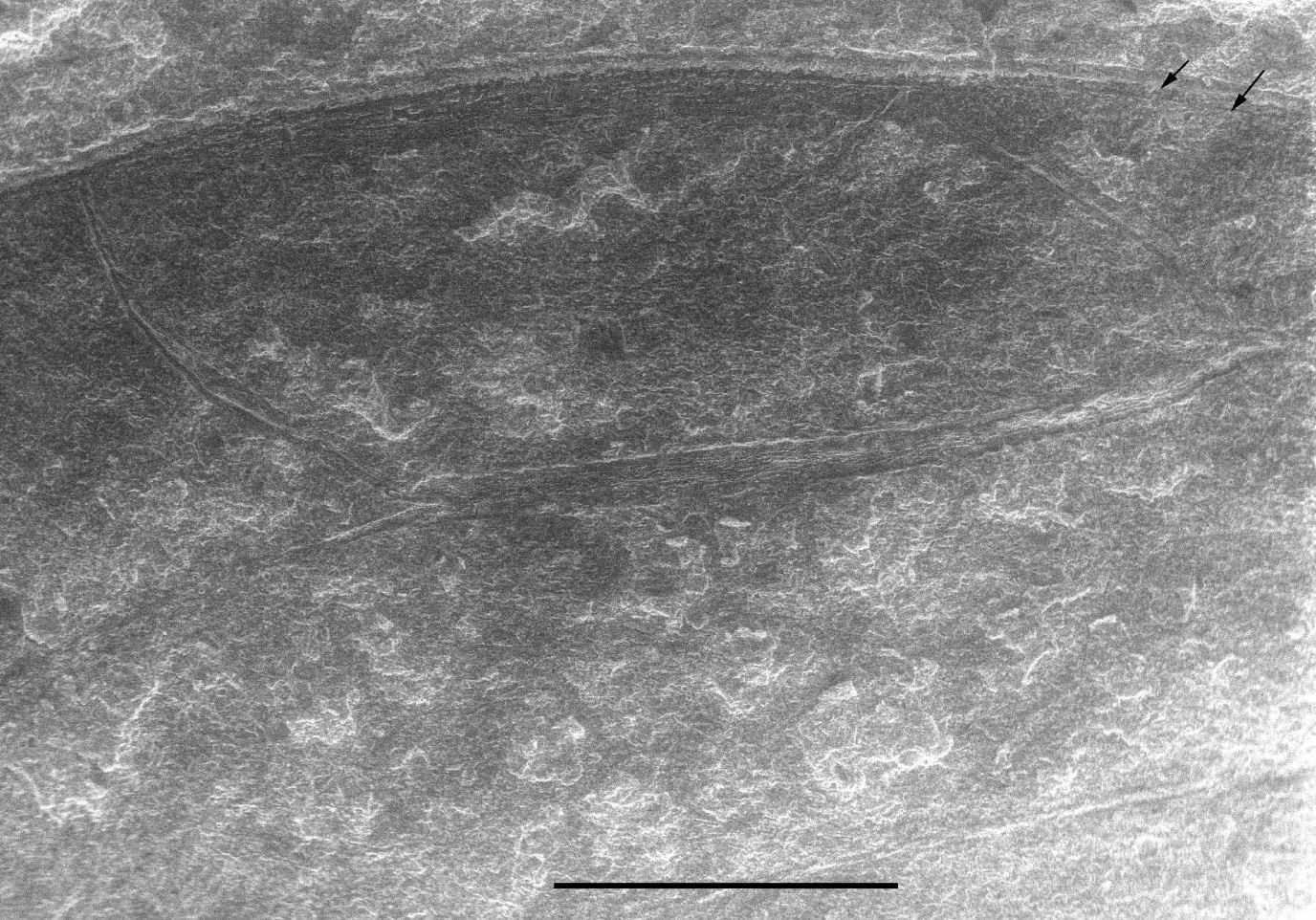

